International Library Review, 16 (3), July 1984, 247-270

\title{
Education and Training of Library Technicians in Czechoslovakia
}

Ian M Johnson*

\section{I ntroduction}

Czechoslovakia, since 1969, has been a federal state of two nations. The Czech Socialist Republic (CSR) covers the western areas of the country, traditionally known as Bohemia and Moravia. The eastern portion, Slovakia, forms the Slovak Socialist Republic (SSR). The educational system is controlled separately by the Ministers of Education in each Republic, but the Federal government takes a close interest in the state and development of educational work.

Since World War II, substantial progress has been made in the development of education in Czechoslovakia, particularly in Slovakia where education had been comparatively neglected by the Austro-Hungarian government prior to the establishment of the Czechoslovakian Republic at the end of World War I. Emphasis has been placed on the development of higher education and, under the influence of the Russian system, with programmes of study adapted to the economic and cultural needs of the country as perceived by government planners.

The aim of schools is to educate the youth and the working people to function as socially useful citizens of the republic. Nine years of compulsory basic schooling, beginning at the age of six, is followed by a four-year secondary programme. This programme can be completed in the "gymnasia" (general secondary schools), in vocational secondary schools, or in apprentice training schools. Students can take the school leaving certificate at any of these types of secondary schools.

The first courses for librarians were offered in Czechoslovakia in 1918, and the first library school was established in 1920 under the control of the Ministry of Education and Culture. A school of librarianship was established in Charles University, Prague, in 1927, but it was re-established in the early 1950s following the amalgamation and re-organisation of three schools of librarianship in Prague.

During the same period, in the early 1950s, the first of the specialist secondary schools was opened, the vocational secondary school for librarians in Brno. Today, there are two university schools of librarianship, in Prague and Bratislava, and three secondary schools for librarians, in Prague, Bratislava and Brno.

\section{The Vocational Secondary Schools}

The vocational secondary school in Prague was established in 1966/67. Its previous accommodation became overcrowded as it built up to its present enrolment, and in 1973 it moved to its present premises, which, quite,

\footnotetext{
College of Librarianship Wales, Aberystwyth, Dyfed SY23 3AS, Wales, UK.
} 
coincidentally, it shares with a secondary school for apprentices which trains bookshop assistants. The Head teacher is in charge of both schools.

The school in Bratislava shares its premises with an apprentice school for graphics artists (Stredna priemselna skola graficka) ${ }^{\dagger}$, with one person as joint Head teacher.

The school in Bratislava was established in 1952, but moved to its present premises about 7 years ago. Apart from conventional classrooms, the school has a specially equipped room for teaching typewriting, a demonstration room for teaching the use of audio-visual equipment and bibliographical work, and a library. The library is little more than a store for books with shelving almost from floor to ceiling, but has a good range of professional texts in Czech and Slovak, and a few titles in English. Computer facilities have been requested for the demonstration room, but have not, so far, been provided.

The school premises in Prague are fairly conventional, and so far no special provision has been made for the teaching of librarianship. The status of secondary schools for apprentices has, however, recently been changed, and they can no longer be housed in the same premises as the vocational schools. Although the course for bookshop assistants was only a part-time one, it did require the allocation of classroom space. The space which is freed by their removal is to be used for a teaching and demonstration library, which should be fitted with appropriate furniture and equipment to the specification of the Ministry of Education's Technical Centre for Libraries. In common with most secondary schools, the vocational school has a language laboratory. Although proud of their own languages, the Czechs and Slovaks recognise the dominance of foreign languages such as English, French, German and Russian in publications concerned with research and development in most fields, and pay great attention to encouraging language skills to facilitate the acquisition of knowledge and experience from other countries.

\section{Teaching Staff}

There are 36 teaching staff in Bratislava, including 8 librarians for teaching professional studies. The other 28 staff include specialists teaching in the artists' school and shared teachers of general academic subjects.

Most of the staff in Prague are general secondary teachers, with their own specialist backgrounds. There are 2 or 3 specialists teaching librarianship and information work, all of whom are graduates of the Department of Librarianship and Information Science at Charles University. A former requirement that teachers should complete postgraduate qualifications before they could be promoted to higher grades has been dropped and none of the specialists in librarianship has a qualification in teaching or a higher degree. However, all teachers in the school participate in re-training programmes offered by the

\footnotetext{
${ }^{\dagger}$ This coincidence probably explains the incomplete reference to a "school for librarians and artists" in Bratislava which appears in the World Guide to Library Schools and Training Courses in Documentation. 2nd edition. UNESCO/Bingley. 1981.
} 
Ministry of Education's Pedagogical Institute, which brings in specialist lecturers, when necessary, to up-date teachers in aspects of librarianship.

There are also opportunities for staff development through participation in the short seminars offered by the University, by UVTEI and by the methodological centres of the library networks, particularly those seminars which concentrate on aspects of teaching and training in the field.

Teachers are required by their contract to spend 19 hours per week in class contact. In practice, they spend an additional 3 or 4 hours per week in a class, but this is treated as overtime and paid accordingly. The professional teachers all have a university qualification in librarianship, but none have a postgraduate qualification in education. One member of staff in Bratislava has recently had 2 years' leave for training in informatics and computer applications, but there are no regular arrangements for this kind of re-training.

\section{Recruitment and Admission}

The school in Prague recruits its students from throughout Bohemia, the western part of the CSR; students from Moravia, the eastern part, attend a similar school in Brno. Advisers in the basic schools are responsible for vocational guidance for students going on to secondary education, but it is recognised that they cannot have a comprehensive knowledge of schools, syllabi and career prospects, and the Ministry organises a week of open days at secondary schools in September or October each year, so that prospective pupils and their parents can form their own impressions. Each year, the school enrols 2 classes, a total of 70 students, into its 4 year programme. Each regional council in Bohemia annually asks for a number of places for students from its area, based on an assessment of the needs of libraries in their area, but entry to the School is competitive and there are more applications (c.100 p.a.) than places. The librarianship course has proved very attractive for girls, many of whom are already unpaid auxiliaries in their local libraries. Only about 6 boys enrol each year.

The school in Bratislava recruits its students from the whole of Slovakia. The Ministry of Education publishes details of its programmes in a regular Bulletin. Information appears in newspapers and periodicals, and there are announcements on radio or television shortly before the entrance examinations. The school is not permitted to produce additional publicity material. There are usually 3 or 4 applicants for every place, and sometimes demand is even higher.

Each year 3 classes, each of about 33 full-time students, are admitted. The number of part-time students is declining, but there are currently about 18 classes, each of 15 students. The school in Bratislava is unusual in that it is the only one of the 3 vocational schools for librarians in Czechoslovakia to offer a programme of overstudies, an additional year of study for school leavers from the gymnasia. The number of students admitted for this programme varies, but each year there are one or 2 classes of about 30 enrolled.

Applications are considered by an Admissions Commission, which in Bratislava comprises the Head teacher, her Deputy and 2 representatives of the local government authority, the National Committee of the Capital of Slovakia Bratislava. About $90 \%$ of admissions are approved by the Admissions 
Commission. The remainder are referred for further consideration to the local government authority.

The entrance examination is of the same standard as all other schools. Apart from the examination results, other factors taken into account in considering applications are the prospective student's basic school leaving certificate and his/her family background. For example, the children of socially deprived families are given preference. The Ministry of Education arranges residential accommodation for students from outlying regions.

No tuition or examination fees are charged. Students in financial need receive grants related to their parents' income. All students receive a range of subsidised services, and grants for practical work periods.

\section{Curriculum development}

The curriculum and syllabus for the school in Prague were developed centrally, at the Czech Research Institute of Vocational Education, which also commissions specialists to write textbooks to support the course. Between them, the staff of the school in Bratislava have written and had published 10 textbooks in aspects of librarianship and information studies. The only consultation with the school was on the number of lessons required to cover each subject satisfactorily. The same syllabus is in use in Brno. In the first 2 years, the curriculum emphasises the student's general education, but in the final 2 years the emphasis switches to librarianship and information work. Details of the curriculum appear as an annex.

The present curriculum appears to have been introduced in 1971/72. A new curriculum is to be introduced in 1984/85, in which it is intended to divide the students into separate streams to prepare for library work in the humanities and information work in the sciences. The staff of the school will advise students about their choice of librarianship or information studies. It is not anticipated that the change in emphasis will affect student recruitment. There is already a greater interest in and emphasis on science studies.

When the new information studies curriculum is introduced, the students will have a common programme with the librarianship students in the first 2 years, and will then divide into 2 separate streams. There is not expected to be any increase in numbers. The proportion entering each stream will be decided by the planners in the Ministry.

\section{Practicum}

Practical experience in libraries is gained by full-time students on a regular weekly basis during term, and in annual blocks also in term, sometime between March and June. The weekly practical sessions are arranged in local libraries, and comprise 2 periods of one hour each week in the second year, 3 periods in the third year and 6 periods in the final year. The annual block of 2 to 3 weeks' full-time fieldwork is usually in a library in the student's home town or somewhere where he/she can find accommodation at reasonable cost and a suitable library is available. The students are allowed to influence the choice, and their geographic, economic and domestic considerations play a part in the 
decision as their financial support from the government for these periods is limited.

Large libraries with staff professionally educated at university level and with which the schools have regular contacts are preferred as hosts for the fieldwork. Whilst the librarians are believed to have an understanding of the school's syllabus, they are reminded in a letter what practical skills they are expected to develop in the students. The libraries' organisation of the fieldwork is monitored, and those which are not fulfilling their agreement are sent a further letter reminding them of what is required. The staff of the schools make supervisory visits to the local libraries which they use for weekly practical training, but the arrangement of the extended fieldwork periods has largely to be left on trust because of lack of funds.

The "continual" practice, which is timetabled each week during term, takes place in local libraries in the second year, to give the students a broad perspective of library work. In Bratislava, 3 staff employed by the town library organise and supervise the practice, and the school pays the library for this work. In the third and fourth years, practice is devoted to bibliographical work, and acquisitions and cataloguing respectively, and these sessions take place in the school.

During the attachment, the students are required to keep a diary of the experience. This is not given a formal mark, but, if it is not satisfactory, the student is not allowed to proceed to the following year. The final fieldwork, immediately before the final year of studies, is intended to give the student an opportunity to gather information for the dissertation which forms part of the final examination. The libraries are asked to evaluate the students by grading various aspects of their performance on a standard questionnaire, but this evaluation also does not formally count in the final examination assessment.

In addition to the fieldwork attachments, undergraduate students make a number of study visits. From Bratislava for example, they go to Matica Slovenska (the Slovak Cultural Centre and national library) at Martin and to libraries in Prague. These visits are in the first and second years respectively. They last 3 days, and the students are accompanied by a tutor. It was longer, but has had to be reduced because of costs. Local visits are also made to libraries and printing houses.

A typical library is the Central Library of the Czech Academy of Sciences, which each year has 5 students from the vocational school in Prague on continual practice, and also takes students for fieldwork attachments. The programmes for these practical training periods are supervised by the Library Deputy Director and by the Head of its Centre for Research and Methodology, and are specifically what is requested by the school of librarianship. For a student from the vocational secondary school, this might be, for example, 2 weeks classifying books using UDC, or operating reprographic equipment. The work is routine, and there is no attempt to create artificial problems for the students to solve, though final year students do use real problems in the library as the basis for their diploma project. It was felt that the programmes arranged did allow the student to gain a general impression of the library, and for the library to assess the student sufficiently to make the report that was requested by the school of librarianship. 
In Slovakia, Matica Slovenska provides training for libraries' senior staff who are likely to be involved in organising in-service training or practical attachments for students from the university or vocational schools. It does not provide detailed guidelines for these attachments, because circumstances differ so much from library to library. However, in consultation with the directors of library networks, Matica Slovenska advises the vocational school of the subjects which students should tackle as their diploma project during their final period of fieldwork.

\section{Assessment}

At the end of the first year, students are allowed to take the "differencia" examination and, if successful, transfer to the second year programme at a gymnasium. As an alternative, they can simply re-sit the gymnasia entrance examination, but, if transferred on this basis, they must repeat the whole of the first year programme.

The Secondary School Leaving Certificate is granted after success in the examinations in 5 subjects: Czech or Slovak language and literature; Russian language; Librarianship; either Acquisitions or Bibliography; and one of the option subjects. There are oral and written examinations.

Written examinations last 4 hours in each subject. In the theoretical subjects, such as Librarianship, students are asked to answer questions on 10 topics. To test their ability in each of the more practical subjects, they are given 5 books, each of which they are asked to catalogue, abstract, prepare a review and note of recommendation to a prospective reader, etc.

The oral examinations last 15 to 25 minutes. Students are given 15 minutes' advance notice of the subjects on which they will be asked questions.

The written examinations are held in April, and the oral examinations in J une, and equal weight is given to both in the final assessment. Results are moderated in the light of overall performance in the school.

Final examination papers are simply graded from 1 to 5 . Grades 1 to 3 represent respectively 'passed excellently', 'passed well' and 'passed'. The average of all subjects, including librarianship, is taken to assess the standard for university entrance. A grade 4 result in any subject automatically reduces the overall average by one point. A student with even one grade 5 result is considered to have failed the whole examination.

If the student fails in 2 subjects in the written examination, he/she is not admitted to the oral examination. If he fails 2 subjects in the oral examination, he has to re-take all the examinations. If he fails only one subject in the oral examination, he is re-admitted to the school for the following semester, and the school's Matriculation Commission specifies a date on which he must re-take the examination in that subject alone.

\section{Part-time Courses}


To cope with the demand for trained staff in the Czech Republic (CSR), the number of part-time students is being increased. The part-time course covers 3 subjects: librarianship; scientific and technical information; and civics and adult education. For librarians or bookshop assistants, the course comprises librarianship, and civics and adult education. Staff from scientific and technical libraries take a combination of courses in librarianship, and scientific and technical information. This latter combination is not always offered because of lower demand.

Students who have already achieved a general secondary school certificate are admitted after only one year working, and can complete the part-time course in 2 years.

For students who did not satisfactorily complete their general secondary school certificate programme, the part-time course lasts 5 years, and incorporates Czech and Russian language studies. The latter subjects are examined in the fourth year, and the 2 vocational subjects in the fifth year. These students are required to have worked for 3 years before they can be admitted to the part-time course.

Attendance on the part-time course is 2 days per month, about 15 to 16 hours' total class contact. There is no organised contact with the students between periods of attendance. Examinations are held at the end of each semester. Students are usually responsible for their own expenses in travelling to the school, and in staying overnight in Prague, if necessary. There are also associated part-time centres outside Prague.

The number of part-time students being admitted in Bratislava for a 3 year programme is being limited by the Ministry because it appears that, as a result of the school's operation over the past 30 years, there is almost a balance between its supply of trained library technicians and the demand for them. Part-time students are enrolled not only in Bratislava, but also in 2 'consultation centres' in Banska Bystrica and Kosice. Admissions at the consultation centres are controlled by the school's Admissions Commission. Students are required to be working in a library or information centre, but standards required in their entrance examination results may not be as high as full-time students or parttime students in the schools.

The school's Deputy Head teachers are responsible for oversight of the consultation centres, but at each there are external part-time teachers coordinated by a Head of Centre. Examinations are conducted by the school staff.

\section{"Overstudies"}

The overstudies programme tends to attract students from the gymnasia who have failed the university entrance examination. Basically, the aim of the programme is to reduce the time taken before students can make a useful contribution to society and the economy. The programme is similar to the school's regular programme, but it emphasises cultural and educational training for archives work, librarianship, and scientific and technical information services. 
The overstudies programme in Slovakia has only recently been reduced to a one year full-time programme. This has been achieved by cutting out the general educational subjects and by reducing the time spent on integral practical training. The change is too recent for the effects to have been evaluated.

The overstudies programme has been discontinued in Prague and Brno.

\section{Higher Education}

Only students who have passed the school leaving certificate are eligible to apply for admission to university. Preference may be given by the universities to applicants who have worked for a year after leaving school before applying. There is also a scheme to allow certain bright workers to take a year's paid leave to complete the school certificate.

Students are admitted to the undergraduate programmes in the University Schools of Librarianship and Information Science primarily on the basis of their secondary school leaving certificate. No special privileges are granted to students who have attended the vocational secondary schools for librarians. Although the programme there was acknowledged as providing good practical training and as giving the students a sound basis for their first year of studies, it was not considered that they were sufficiently advanced in the theory of librarianship and in language studies to be granted exemption from any part of the undergraduate programme.

Twelve students from the school in Prague went on to study in the Department of Library Science in Charles University at the start of the 1981/82 session, but this was an exceptional number. Normally, only about 5 or 6 each year proceed to higher education in librarianship.

\section{Employment}

On completion of the programme, the students are able to apply for jobs notified to the school by the Ministry or directly by the library networks. In most of Czechoslovakia, it is relatively easy for them to get jobs, but it is more difficult in Bratislava. Some employers still operate their own entrance examination competition.

Even those students who are weak in their understanding of the theory tend to be satisfactory in their practical work, so they have no problem in getting jobs. Good students can be choosy about which job they take. The school receives from the Ministry a list of available jobs, but employing organisations frequently write directly to the school with offers of jobs.

A typical starting salary is around Kcs 1400 per month, although some students prefer to take part-time posts on lower salaries. Students take jobs in a variety of organisations, mainly public 'cultural' libraries, but many choose jobs in scientific and technical libraries, where salaries and conditions of service can be better.

\section{Manpower planning}


Consultation between the Ministry of Education and other Ministries about manpower requirements appears not to have been effective. There are more jobs available than the number of students completing the programme.

There has, however, been little or no increase in the number of full-time places available in the schools of librarianship. The number of secondary school leavers gaining the qualifications necessary for university admission is insufficient to meet existing demands for high level manpower, and student places cannot be transferred from the gymnasia to the vocational schools. Moreover, it seems that increasing the number of places for full-time students of librarianship and information management might necessitate re-directing potential workers away from other employment sectors which the government considers to be more economically desirable and places cannot therefore be transferred from other vocational and apprentice schools.

Facilities for part-time students have been substantially increased in recent years to allow workers who have entered the library and information field from other disciplines to gain an appropriate qualification. The places on part-time courses at the secondary schools of librarianship are, however, a fixed number, and demand for places exceeds availability.

In consequence, there has grown up a parallel training system, initiated and supported by the methodological centres of the libraries at the centres of networks. They aim to provide training, not only for the library staff in their networks, but also for the library users to make them more self-reliant.

\section{The Library Networks}

Because of the federal nature of Czechoslovakia, there are two main library networks. In the CSR, the network is based on the Czech State Library in Prague. In the SSR, Matica Slovenska acts as the Slovak National Library, but, because it is located in Martin, over 100 miles from the major city in Slovakia, the University Library in Bratislava has been assigned the international role in the network in collection building and interlending.

The National Libraries, at the head of all the networks, co-ordinate bibliographic activity, research and professional publications, continuing education, and international relations. The Czech State Library and Matica Slovenska are also the centres of networks of public libraries, which are organised on a regional and district basis, in parallel with the rest of the country's administration.

Other networks are organised to encompass libraries with a common purpose or specialisation, e.g. school libraries, agricultural libraries, technical libraries, trade union libraries. Each network is headed by a Central Library, which is usually in the institution which most needs and uses information in the field.

Each Central Library has a "methodological" role in respect of its network of libraries, which is a form of managing the network. Through a series of surveys and analyses, the methodological centres collect and interpret information and statistical data for planning, decision making and control of the network. As well as planning long term development, they attempt to co-ordinate and standardise new activities. This is achieved through a regular programme of publications, 
and through attention to the continuing education, training and re-training of library staffs.

\section{Federal Provision}

At a Federal level, the Institute of Continuing Education of the Centre for Scientific, Technical and Economic Information (UVTEI) is seeking to overcome the problems arising from the limited number of students produced by both the university and secondary schools of librarianship. UVTEI initiated the part-time programme at the vocational secondary schools for graduates from the gymnasia who have moved into librarianship and information work, but it has been recognised that the number of secondary school graduates available for higher education or employment in other types of work is insufficient to meet the priority demands of industry, and the number allowed to enter the schools of librarianship is consequently limited by the Ministry of Education's planners.

UVTEI therefore also organises its own courses with the approval of the Ministries of Education. For secondary school graduates without previous formal education in librarianship, the Institute organises its own specialised part-time course in information systems, comprising 230 hours of class contact over 3 semesters. An outline syllabus appears as Appendix 2. It bears some similarity to the vocational secondary school curriculum, but the UVTEI programme is claimed to be more flexible in adapting to current practice and new developments.

To enable it to identify the courses which are needed, the Institute carries out research into the operation of the national information system, examines the networks' plans for future development, and consults widely throughout the system. These consultations culminate in discussions in the Scientific Pedagogical Council, which comprises representatives of the information networks. The Council reviews future plans and the evaluation of courses completed by students who took part, and every 3 to 5 years determines what short and long courses should be provided.

Attendance at these short and long courses is paid for by the student's employer. Apart from the student's travel and accommodation, a fee is charged to cover the cost of tuition and textbooks, and to make a contribution to the Institute's overheads. The fee reflects the size of the group. Language courses, for example, necessitate teaching in smaller groups, and higher fees are charged. Nonetheless, courses are popular and well attended, and none have failed to attract sufficient support to make them viable.

For some students, their employment is conditional upon attendance at a particular course, but not necessarily upon satisfactorily completing the examination with which most courses conclude. However, students who do not sit the examinations are usually required to pay the fees back to their employer. Satisfactory completion of the courses is not normally recognised for salary purposes, although students completing the language courses qualify for a small salary supplement.

Some examinations demand written work, but most are simply oral examinations. With the exception of short language and computer courses, 
there is an interval after the course to allow the student to prepare for the examination. The student's examination result is graded, and he is given a copy of the certificate. It is possible for a student to revise the subject and re-take the examination to try to get a higher grade if he wishes, or if it is considered necessary.

UVTEI has been publishing in the field of librarianship and information science since 1951, and now reviews its publication plans annually. Its editorial staff recruit authors from amongst known specialists, who are willing to write in their own time for a fee. In addition to books, some tape-slide programmes have also been commissioned.

\section{National and Network Provision}

The Czech State Library Centre for Research and Methodology in Librarianship runs its own one year training course for university graduates with no previous training in librarianship, taught by the staff of the Department of Librarianship and Information Science at Charles University, Prague, but it does not provide a comparable programme with outside instructors for staff who enter its service with the secondary school leaving certificate. However, as the vocational secondary school for librarians is not producing enough trained people to meet demand, the State Library does operate a training programme for library assistants in its own employ and in the public library network, using its own staff as instructors. Its training programme for these former secondary school students can include language training.

The Centre is also developing continuing education for library staff within the framework of the Czech Republic's general adult further education programme. A programme of 7 one-week courses, aimed at all levels of staff in the public (cultural) libraries network, was held over a 21/2 year period from 1977-79, covering Marxism and Leninism, cultural policy, management theory, personnel management, legal aspects, and selected topics in librarianship - e.g.

centralisation, work with political literature, work with children, international organisations, audio-visual materials. At the end of the programme, the students were required to write a review of what they had learned and how it applied to their job.

Attendance was compulsory, and all expenses were paid. There were, however, problems because of the amount of time employees were away from their work, and some of the courses were not felt to be particularly relevant to their work. The programme is now being re-organised with more emphasis on professional topics. It will in future comprise only 4 one-week courses, but $50 \%$ of the time will be devoted to professional topics.

The Czech Academy of Sciences, Central Library - Centre of Scientific Information manages to attract an adequate supply of new recruits from the Department of Librarianship and Information Science at Charles University, but there are never sufficient graduates from the vocational secondary schools for librarians available. The libraries of the research institutes which form the network based on the Academy are comparatively small, and have even greater difficulty in recruiting. Most of their library and information staff have had no formal professional education when appointed. 
For its own new recruits, the Academy's Central Library organises an extended induction programme, in which the trainee spends one month in each of the 8 departments: acquisitions, processing, reader services, methodological, retrospective bibliography, reprographics and science advertising.

In Slovakia, the planning process at Matica Slovenska identifies course content and dates well in advance. Information on their plans from the library networks enables an overall calendar to be co-ordinated, ensuring that libraries are not faced with a clash of events which might prevent them releasing an individual member of staff.

The planning process also covers the textbooks required to support its own courses and other professional programmes. A 5-year planning period is used. Although plans become more concrete as the specified year approaches, this does not appear to be a flexible rolling programme. Currently, the plan for 1981-85 is being implemented, and the plan for 1986-90 is being drawn up, including the subjects of publications proposed for issue in each of those years.

Textbooks are prepared by the group teaching the course, on the basis of outlines and guidelines provided by Matica Slovenska. Texts have been written to support 3 specialised courses in the last 3 years, and about 150-200 copies of each title have been printed. It is intended to provide training for instructors in teaching techniques and textbook writing.

Comenius University, Bratislava, co-operates with the methodological centres of the library networks in Slovakia in mounting appropriate short courses. About 15 short courses were run in the previous year in which part or all of the teaching was undertaken by the Department's staff. In each case, the organisation was undertaken by the central library of the network, and the course was financially supported by libraries in the network.

The Department also collaborates with the Slovak Technical Library in developing a programme of courses to meet their specialist needs at "apprentice" level. The Department's staff undertake some of the teaching, and carry out the examination process. Trainees who complete the course, which is at about Secondary School Certificate level, are awarded the Technical Library's own Certificate of Higher Qualification.

\section{Conclusions}

The Czechoslovakian authorities have created a particularly relevant and effective library technician programme in the Vocational Secondary Schools. By including provision for full-time education and training for library and information work in their secondary schools, they have gone a long way towards overcoming a problem prevalent in the "capitalist" countries, i.e. ensuring a supply of trained manpower. It also appears to offer a good balance between general education and language skills, both of which are essential for library staff, and library studies. 
However, the impact of limited (and diminishing) funds and the rigid state management system were clearly minimising the potential for innovation and improvement.

A primary requirement of any school of librarianship is a first-class library, but not one of the vocational schools had this facility. Library and laboratory facilities for demonstration and practice within the schools of librarianship are limited in range and quality, and this must diminish their effectiveness.

Practical training is accepted as an integral part of all levels of education for librarianship and information work. In the case of the vocational secondary schools, the major emphasis of the specialist part of the programme is, correctly, on developing the student's ability to carry out a range of pre-determined tasks at a technician level. Although a detailed study of the arrangements made for students' practical training by individual libraries has not been undertaken, it is probably safe to assume that they are successful in terms of the generally undemanding nature of the programmes requested by the schools of librarianship. Despite the elementary nature of the attachments, these periods of practical experience probably make a significant contribution to the training of the pupils of the vocational secondary schools.

However, economic constraints on staff numbers, staff travel, and student travel and subsistence narrow the choice of libraries which can be used for fieldwork attachments. For example, students living in remote country areas may not have easy access to the kind of information centre which could offer appropriate experience. Opportunities to develop more demanding programmes for the periods of practical experience, which will be necessary as the complexity of library and information work increases and compels greater delegation of tasks at present performed by university graduates, are minimised by a system which limits regular personal contacts between teachers and practitioners. If there is no change in this situation, there will be particular problems in developing the skills of students opting to take the information science programme.

It was, however, interesting to note the heavy use of students to resolve real problems in library services by carrying out projects as part of their fieldwork. This is a development which would be encouraged in the best of circumstances. In Czechoslovakia, where most people appear to have few real incentives to motivate them to improve their own and their library's performance, one must suspect the reasons underlying this practice, but one cannot deny that these projects offer a potentially substantial contribution to the development of library services.

There seems to be little real co-ordination between the planners in the various Ministries, so far as meeting manpower needs in library and information work is concerned. Moreover, although the library and information networks are effectively designed to transfer knowledge and technology from abroad to within Czechoslovakia, and to do it economically through the co-ordinated purchasing and cataloguing of literature from the 'hard currency' countries, the low priority apparently attached to the education and training of librarians by the Ministries and their planners suggests that they have not yet fully appreciated the potential role of an effective library network in the economic development of the country. 
Continuing education for workers in libraries and information centres is critically important, not only because of changing techniques and technology in their own work, but also because information resources in all fields of knowledge are expanding rapidly. It is unfortunate that in Czechoslovakia much of the effort which in other countries is directed into organising continuing education programmes is expended on providing part-time post-entry education leading to basic qualifications, reducing the human and financial resources available for genuine continuing education.

That emphasis reflects the apparent failure of the planners to identify the manpower required and to ensure that a more realistic number of places are available on full-time programmes in the universities and vocational secondary schools, which are more efficient and more effective than part-time courses.

The standard of part-time courses taught at the schools of librarianship in Czechoslovakia appears to be good, but the lack of sustained contact and effort between attendances diminishes their effectiveness. A system of "guaranteed employment" in which individuals are allocated to vacant posts without necessarily any reference to their qualifications or suitability operates in Czechoslovakia, and this could lead to many people being transferred to work in libraries who are not highly motivated towards their work. The evidence of large numbers taking part-time programmes of study to qualify may be seen as a retort to that fear, but it is not unreasonable to suppose that many students are simply motivated by the opportunity to take time off work. There are few real rewards for successfully completing the course or for the improved performance one can expect from a trained professional.

The regular staff of the schools of librarianship are not able to be involved in teaching in the zonal sub-centres to any significant extent, and a review of standards and effectiveness there might also reveal weaknesses.

The production and distribution of sound professional textbooks and journals in sufficient quantities can help overcome this in a limited way, as well as contributing to the informal continuing education of interested individuals. It does, however, seem unusual that a state system which controls both education and broadcasting has not brought the two together to establish distance learning programmes. Such a development might go a long way towards overcoming the problems of lack of contact between attendances on part-time courses and the limited teaching expertise available in the consultation centres, but a programme of work would need to be assigned to the students to ensure that they had sustained their efforts, and additional teaching staff would therefore be needed not only for preparing broadcasts but also for assessing essays, etc.

Such a development requires a broad perspective of what is needed and the availability of substantial resources to meet the need. The planning system operated by the networks and their methodological centres is designed principally to ensure steady development and orderly allocation of limited resources. It appeared that this process was being applied in such detail over the whole period of a 5-year plan that it obscured fundamental problems and also offered little scope for response to sudden changes. However, some organisations were beginning to plan their activities on the basis of an agreed 
but only broadly defined programme, and this seems a development which should be encouraged.

It may be significant that what appears, on an initial and admittedly brief examination, to be a particularly successful programme for educating and training library technicians was initiated outside the mainstream planning activities of the library networks and their methodological centres, and that it is the rigidity of the planning system which appears to be frustrating aspects of its development. A closer examination is needed of the type of work undertaken by the products of these vocational secondary schools, of how the curriculum is developed and the output of the schools managed and of the relationship between the schools and the practitioners. Nonetheless, the programme has much to commend it and, with allowances for local circumstances, is one which could perhaps be considered as a model for those developing countries which have a shortage of staff properly trained to deliver the library and information services needed to support educational and economic development but which, because of limited resources, have to rely on a small cadre of professionals and, for their vitally important support staff, on the products of their own education system. It also calls for closer examination by the more developed countries, which have mostly failed so far to find a successful pattern of education and training for staff working at this level.

\section{APPENDIX 1}

\section{Vocational Secondary School for Librarians, Prague}

Curriculum approved 1971/72

Subject Number of periods per week

\section{Year}

$\begin{array}{llll}\text { I } & \text { II } & \text { III } & \text { IV }\end{array}$

Social sciences and languages

Czech language

Russian language

English or German

Civics

History

General Studies

$\begin{array}{llll}2 & 2 & 2 & - \\ 2 & 2 & 2 & 2 \\ 3 & 3 & 3 & 3 \\ 1 & 1 & 2 & 2 \\ 2 & 2 & 3 & - \\ 2 & 2 & - & -\end{array}$

Maths and Sciences

Mathematics

Physics

Chemistry

Biology

$\begin{array}{llll}3 & 2 & 2 & - \\ 2 & 2 & - & - \\ 2 & 2 & - & - \\ 2 & - & - & -\end{array}$

Basic Vocational

Cultural policy 
Vocational

$\begin{array}{lllll}\text { Czech, Slovak and World Literature } & 3 & 3 & 5 & 5 \\ \text { Acquisitions and Cataloguing } & 2 & 3 & 3 & 3 \\ \text { Bibliography and Informatics } & - & 2 & 2 & 3 \\ \text { Librarianship* } & 2 & 2 & 2 & 2 \\ \begin{array}{l}\text { Practicum } \\ \text { Physical Exercise }\end{array} & - & 2 & 3 & 6 \\ \text { Options } & 3 & 3 & 3 & 2 \\ \text { Latin } & & & & \\ \text { English or German } & 2 & 2 & 2 & 2 \\ \text { Foreign Language Conversation } & 2 & 2 & 2 & 2 \\ \text { Music } & - & - & 2 & 2 \\ \text { Sport } & 2 & 2 & - & - \\ & 2 & 2 & 2 & 2\end{array}$

*The librarianship course comprises:-

Year 1 Library history

2 Organisation and management of libraries

Libraries in different countries

$3 \quad$ Planning and economic management

$4 \quad$ General methodological approach

Reader service and psychology

Inter-library co-operation

Pedagogy

Scientific literature

\section{APPENDIX 2}

\section{Central Office of Scientific, Technical and Economic I nformation (UVTEI)}

INSTITUTE FOR CONTINUING EDUCATION

"Information systems" course for secondary school graduates without previous relevant vocational education

N.B. This is reproduced verbatim from an incomplete photocopy of an original document.

1 Selected Chapters of Marxism-Leninism

Stages of development of rationalisation (thought) prior to the emergence of Marxism-Leninism. Emergence of Marxism- Leninism as a revolution in theory and practice. Laws and regularities of dialectic materialism and selected categories of Marxist dialectics. Basic problems of Marxism-Leninism. MarxistLeninist concept of values and a value orientation. Marxism-Leninism on the role of man in socialist society. 
10 hours

2 Scientific and Technological Revolution and Socialist Economic Integration

Scientific and technological revolution as a process. International division of labour in the period of STR. Socialist international division of labour. Economic integration in the world socialist economic system. Complex programme of further deepening and improvement of co-operation and development of socialist economic integration of the CMEA member states.

10 hours

\section{Creative and System Thinking}

Substance of a system approach and substance of a system science. Principal working methods common to all system disciplines. Main system theories. Operational analysis. System analysis. Practical example of the application of system analysis to activities in the STEI area. System engineering. Practical effects of newly-acquired knowledge. Anticipated development of the system science and its disciplines.

10 hours

\section{Information Systems (25 hours)}

\subsection{Introduction to Studies}

STEI as theoretical branch and as practical activities. Interpretation of basic notions of information science. Properties required of personal characteristics and qualification of an information worker. Methodology of studies of scientific, technical and economic information. Information services, funds and sources to study STEI.

5 hours

4.2 Organisation and Management of National Economy and significance of STEI .

Development of national economy in a socialist society. Social process of reproduction. Planned management of national economy. Branch management of national economy. Social process of gaining knowledge. Role of science and technology in society.

\section{3 (Missing)}

4.4 (Missing)

\subsection{Management of an Information Unit}

Principles applied to the establishment of information centres. Internal structure of STEI units. Organisational arrangement of a STEI unit in the framework of a 
factory, enterprise, institute. Advisory bodies in information units. Co-operation with other departments within the same organisation. Organisation and equipment of a workplace. Manpower, use of external collaborators. Planning activities in STEI units.

\section{5 hours}

\section{Information Sources (20 hours)}

\subsection{Typology of Information Sources}

Principles applied to communication process and the role of information sources. Typology of information sources in accordance with such criteria as availability, ways of fixing information, contents. Documents and their classification.

Classification in accordance with Project MARC II. Characteristics of individual types of information sources (books, periodicals, special documents, non-literary sources).

\section{5 hours}

\subsection{Acquisition of Information Sources}

Principles applied to creation of information funds. Definition of an information fund. Sources of information on different types of information sources. Criteria for selection of information sources for a concrete fund. Methodology of acquisition of information sources (concrete procedures in use in different territorial areas). Means of registration of new additions to information sources.

\section{5 hours}

\subsection{Creation and Exploitation of Funds of Primary Information Sources}

Principles applied to organisation and protection of funds. Care for funds. Responsibility for funds. Interpretation of directives bearing upon registration and revision of funds. Registration of primary information sources, scale and kinds. Dislocation and storage of funds. Revision of funds and bringing funds up-to-date. Organisation of services and registration systems of the service. Use and availability of funds through such forms as lending, copying and micro filming services. Bibliographical and informational work. Mechanisation of services. Statistics on the use of funds.

\section{0 hours}

\section{Identification Description (15 hours)}

\subsection{Basic notions}

Record of a document. Basic structure of a full record of a document. Characteristics of individual elements of an entry, their functions and interconnections. Record (entry) in bibliography and cataloguing. Identification records and identification description. Basic instructions and regulations. 
5 hours

\subsection{General Methodology of an Identification Description}

Analysis of a document for the purpose of identification description. Procedure and aims of analysis. Description unit, definition of term and its significance for the processing of documents. Description under author and description under title. Other data in the identification record (entry). General rules of description.

\section{5 hours}

\subsection{Special Methodology of an Identification Description}

Inter-relationship between general and special methodologies of an identification description. Analytical identification record (entry) and its structure. Creation of an analytical identification record (entry) in accordance with individual types of information sources. Modifications of an identification record (entry) as used for catalogues, bibliographies and research items. Applications in mechanised systems.

\section{5 hours}

7 Content Analysis and Topical Classification of Information“ (30 hours)

\subsection{Content Analysis of an Information Source}

Subject of an information analysis of the text. Content and language structure of a special text. Methods of text analysis. Informational picture of the text. Stages of an information analysis of the text. Methodology of annotations. Methodology of reporting. Use of information analysis of texts in the process of input and output procession. Laboratory work.

5 hours

\subsection{Universal Decimal Classification (UDC)}

UDC as a selection language and its significance from the standpoint of an overall organised information process. Information process and the role of a selection language. UDC as a selection language. UDC, description and methodology of application. UDC tables and forms of UDC further development.

10 hours

\subsection{Systems of Making Entries \\ Basic problems of classification}

Effectiveness of a classification system. Quanta of Bool algebraics. System of look-through cards as a basic pattern for storage and retrieval of information. Group classification. KWIC and KWOC systems. Documentation selection language. Thesauri. Definition of a thesaurus. Survey and description of best known thesauri. Methodology of creation of a thesaurus. Semi-operation and operation of a thesaurus. 
15 hours

8 Systems of Storage, Retrieval and Dissemination of Information (35 hours)

\subsection{Essentials of Bibliography}

Substance and role of bibliography. Basic types of bibliographies. Application of identification description in bibliographical work. Bibliographic description and catalogue description. Applications of methods pertaining to annotations, reports, reviews and Current Contents. Application of analytical description. Present situation in bibliography in the C.S.S.R. Special bibliographies. Methodology of special bibliographies. International systems of bibliographic procession of literature.

5 hours

\subsection{Secondary Sources of Information}

Catalogues aimed at creation and use of general and central catalogues. Documentation card files, their function from the standpoint of selection and dissemination of information. Bibliographic lists. Report journals. Central registration.

\section{5 hours}

\subsection{Research and Study Activities}

Definition of research study. Methodology of research study. Main phases of research study. Ways of retrieving information from information funds. Kinds of studies. Structure and formalisation of study papers. Planning research studies. Study and analytical activities as subsequent steps to research. Characterisation of these activities. Procedures applied to study and research activities. Kinds of analytical reports and study papers.

\section{5 hours}

\subsection{Factual Information}

Classification of factual information in accordance with its type, purpose and information topics. Technology of processing of factual information: data collection, data analysis, input data processing, retrieval, synthesis and use of data. Development of factual information systems.

\section{5 hours}

\subsection{Internal Publication-Related Activities (including copyright)}

Role of publication-related activities in information process. Organisation of planning and execution of publication-related activities. Editorial work on manuscripts. Kinds of publications edited by information centres. Distribution of publications. Copyright and its application in the STEI area. 
15 hours

9 Industrial Legal Protection and Technical Standardisation (15 hours)

\subsection{Industrial Legal Protection and Patent Information}

Importance of patent information for the development of national economy. Emergence and development of legal protection of discoveries. Legal protection of industrial rights. International patent right. Patent classification. Patent research and types of research. Methodology of patent research. New methods of patent information processing.

10 hours

\subsection{Technical Standardisation}

Notion and its development (in brief). Law on technical standardisation No. 96/64 of the Collection of laws. Classification of technical standards. Construction, structure and formal arrangement of technical standards in the C.S.S.R. International standardisation. Standardisation in the STEI area. Standardisation literature as a source of scientific, technical and economic information. Metrology and qualimetry.

\section{5 hours}

10 New Methods and Means of Storage, Retrieval and Dissemination of Information (50 hours)

\subsection{Means of Organisational Technology (including Reprography)}

The term of reprography. Structure of the branch of reprography. Preparation of originals and matrixes. Typewriting machines, kinds, technology and application. Multiplying machines and techniques. Micrography. Combination of reprographic technologies. Final arrangement of prints and copies (treatment).

10 hours

\subsection{Small Mechanical Selection Systems}

Creation of artificial memories. System of uniterm cards. System of lookthrough cards. System of notched cards. System of slot cards.

\section{5 hours}

\subsection{Automated Information Systems}

System of computation. Memory and recording media and structure of an information entry. Organisation of sets. Organisation of work of the computer. Setting tasks for programming. Application of computing technology in the area of scientific, technical and economic information. STEI processing as a function of programme systems. Survey of applications of computing technology in the 
STEI area in the C.S.S.R. and elsewhere in the world. Magnetic tape services. State information policy in the C.S.S.R. with reference to the introduction of computing technology in the STEI area. System of Central Technical Base. Survey and content of automated agendas within the Central Technical Base. Contemporary programmes for information systems produced in the C.S.S.R. from the standpoint of domestic and international integration. Unified STEI software system in the C.S.S.R.

25 hours

11 Requirements of Information Consumers (10 hours)

\subsection{Profiles of Consumers, Survey and Satisfaction of Consumers' Needs}

Concept of a consumer of information. Information requirements of consumers. Typology of consumers. Information demands, their identification and satisfaction. Information profiles and their definition. Measurement of effectiveness of information services.

\section{5 hours}

11.2 Dissemination of Information, Preparation of Consumers for Work with Information

Relation of a consumer to an information system. Advertisement of information funds and services. Informational level of a consumer. Preparation of information consumers.

5 hours

\section{APPENDI X 3}

\section{FURTHER READI NG}

JAVORCIKOVA, Anna. Obsah, metody, a formy vychovy. (Education syllabuses, educational methodology and forms of education.) Kniznice a Vedecke Informacie, 8 (3) 1976, 132-136. In Slovak.

JAVORCIKOVA, Anna. Inovacia vychovy a vzdelavania na strednych knihovnickych Skolach. (Educational innovation in the colleges of librarianship.) Citatel, 27 (4) 1978, 124-125. In Slovak.

KUGLEROVA, Jana, and ULBRICHOVA, Milada. Cinnost UVTEI ve vychove a vzdelavani pracovniku soustavy VTEI. (The activities of COSTEI in the education and training of scientific and technical information workers.) Ceskoslovenska Informatika, 22 (1) 1980, 17-22. In Czech.

MARUNIAK, Peter. Libraries in the Czechoslovak Socialist Republic. 1978. Matica Slovenska. In English.

NAKONECNY, Milan, and HELBICHOVA, Danuse. Motivacni a postojove aspekty ke studiu knihovnictvi na stredni knihovnicke skole. 1980. Statni knihovna CSR. (Motivation and 
approach to aspects of learning librarianship in the vocational secondary schools for librarians). In Czech.

ŠPIVOLUSKOVA, Terezia. Studium popri zamestnani na strednej knihovnickej skole. (Part-time courses at the College of Librarianship.) Citatel, 27 (2) 1978, (4 page inset). In Slovak.

ULBRICHOVA, Milada, editor . Pedagogicke a didakticke metody $v$ informatickem vzdelavani. 1977. UVTEl. (Pedagogic and didactic methods in education for information workers: proceedings of a seminar for teachers and specialists in scientific, technical and economic information, 2-4 May 1977, at Karlovy Vary). In Czech.

ULBRICHOVA, Milada, editor. Pedagogicko-psychologicke otazky informatickeho vzdelavani. 1979. UVTEl. (Pedagogical and psychological problems in education for information science: proceedings of a seminar for specialists and teachers in scientific, technical and economic information, 24-26 April 1978, at J evanech). In Czech.

WHATLEY, H.A. Czechoslovakia. In: Education for librarianship: an outline of development in 25 countries. Glasgow. University of Strathclyde. 1968. (M.A. Thesis) pp. 150-158. 